
VOLUME 10 NOMOR 6 DESEMBER 2021

ISSN : 2303-1514 | E-ISSN : 2598-5949

\title{
IMPLEMENTASI KOMPETENSI KEPRIBADIAN GURU DALAM PENGUATAN KARAKTER RELIGIUS PESERTA DIDIK MELALUI PEMBIASAAN DI KELAS IV MIN 2 SERANG
}

\author{
Lulu Rauhah ${ }^{1}$, Istinganatul Nguluwiyah ${ }^{2}$, Ikman Nur Rahman ${ }^{3}$ \\ ${ }^{1,2,3}$ Universitas Sultan Ageng Tirtayasa, Serang, Indonesia \\ ${ }^{1}$ lulurauhah19@gmail.com, ${ }^{2}$ istinganatul@untirta.ac.id, \\ 3ikman_rahman@untirta.ac.id.
}

\section{THE IMPLEMENTATION OF TEACHERS' PERSONALITY COMPETENCE IN STRENGTHENING THE STUDENTS' RELIGIOUS CHARACTER THROUGH HABITUATION AT GRADE IV MIN 2 SERANG}

\begin{tabular}{|c|c|}
\hline ARTICLE HISTORY & ABSTRACT \\
\hline $\begin{array}{l}\text { Submitted: } \\
\text { 11 Juli } 2021 \\
11^{\text {th }} \text { July } 2021\end{array}$ & $\begin{array}{l}\text { Abstract: Teachers have a crucial role in achieving educational goals, especially to strengthen } \\
\text { the students' religious character. In everyday life, a child often imitates what is done by people } \\
\text { he usually meets because one of the characteristics of students at school age is imitating } \\
\text { others. Therefore, a teacher with a good personality will more easily have a positive impact on } \\
\text { strengthening the students' religious character. This study aimed to determine teachers' } \\
\text { personality competence in strengthening the students' religious character through habituation } \\
\text { at grade IV MIN } 2 \text { Serang. The research method used in this research was descriptive } \\
\text { qualitative. Data collection techniques used were interviews, observation, and documentation. } \\
\text { This study indicated that the teacher of grade IV MIN } 2 \text { Serang had the personal abilities to } \\
\text { reflect his personality. The teacher was able to implement personality competencies to } \\
\text { strengthen the students' religious character and provided good results in strengthening the } \\
\text { students' religious character. }\end{array}$ \\
\hline
\end{tabular}

Keywords: teacher's personality competence, religious character

Accepted:

04 November 2021

$04^{\text {th }}$ November 2021

Published:

27 Desember 2021

$27^{\text {th }}$ December 2021
Abstrak: Guru memiliki peran yang sangat penting dalam mencapai tujuan pendidikan, khususnya dalam rangka memperkuat karakter religius peserta didik. Dalam kehidupan sehari-hari sering kali seorang anak menirukan apa yang dilakukan oleh orang yang sering ditemui nya, karena salah satu karakteristik peserta didik pada usia sekolah dasar adalah senang meniru. Oleh karenanya Seorang guru dengan kepribadian yang baik akan lebih banyak dan lebih mudah memberikan dampak positif terhadap penguatan karakter religius peserta didik. Penelitian ini bertujuan untuk mengetahui implementasi kompetensi kepribadian guru dalam penguatan karakter religius peserta didik melalui pembiasaan di kelas IV MIN 2 Serang. Metode penelitian yang digunakan dalam penelitian ini adalah kualitatif deskriptif, teknik pengumpulan data yang digunakan adalah wawancara, observasi dan dokumentasi. Hasil dari penelitian ini bahwa guru kelas IV MIN 2 Serang telah memiliki kemampuan personal yang dimiliki oleh guru dalam mencerminkan kepribadiannya, mampu mengimplementasi kompetensi kepribadian untuk memperkuat karakter religious peserta didik serta memberikan hasil yang baik terhadap penguatan karakter religius peserta didik.

Kata Kunci: kompetensi kepribadian guru, karakter religious

CITATION

Rauhah, L., Nguluwiyah, I., \& Rahman, I. N. (2021). Implementasi Kompetensi Kepribadian Guru Dalam Penguatan Karakter Religius Peserta Didik Melalui Pembiasaan Di Kelas IV MIN 2 Serang. Primary: Jurnal Pendidikan Guru Sekolah Dasar, 10 (6), 1643-1653. DOI: http://dx.doi.org/10.33578/jpfkip.v10i6.8351. 


\section{PENDAHULUAN}

Dalam Undang-Undang Sistem Pendidikan Nasional dikemukakan bahwa pendidikan adalah usaha sadar dan terencana untuk mewujudkan suasana belajar dan proses pembelajaran agar peserta didik secara aktif mengembangkan potensi dirinya untuk memiliki kekuatan spiritual keagamaan, pengendalian diri, kepribadian, akhlak mulia, serta keterammpilan yang diperlukan dirinya, masyarakat, bangsa, dan negara (UU RI. No. 20 Tahun 2003 tentang Sistem Pendidikan Nasional BAB I pasal 1 ayat 1)

Berdasarkan Undang-Undang Sistem Pendidikan Nasional No. 20 Tahun 2003 BAB I pasal 1 ayat 1 bahwa pendidikan bertujuan untuk memberi perubahan serta perkembangan kemampuan kepada peserta didik, dari yang tidak tahu menjadi tahu, dari yang tidak bermoral menjadi memiliki moral dan dari yang tidak bisa menjadi bisa. Pendidikan sangat diharapkan untuk mengembangkan kualitas, minat, bakat, serta potensi yang dimiliki oleh peserta didik. Oleh karena itu kegiatan dan tujuan pendidikan tidak hanya terfokus pada satu aspek kognitif nya saja tetapi harus mencakup seluruh dimensi peserta didik, mulai dari perkembangan kognitif, perkembangan afektif, dan perkembangan psikomotorik.

Untuk mewujudkan tujuan tersebut maka sangat diperlukan pendidikan yang berkualitas yang dapat menciptakan generasigenerasi penerus bangsa yang bermutu, namun sistem pendidikan di Indonesia saat ini masih belum dapat dikatakan berkualitas. Menurut survei Political and Economic Risk Konsultan (PERC), kualitas pendidikan Indonesia menempati urutan 12 dari 12 negara se Asia (Martinus, 2020). Ada beberapa hal yang membuat rendahnya kualitas pendidikan di Indonesia seperti, belum meratanya kualitas pendidikan di suatu daerah dengan daerah lain, kurang memadainya sarana prasarana sekolah bahkan sampai permasalahan rusak nya moral para peserta didik sebagai objek utama yang menerima dampak dari kegiatan pendidikan.
Salah satu topik utama yang sering di bahas dalam dunia pendidikan yaitu penyimpangan moral karakter peserta didik. Berdasarkan data International Center for Research on Women (ICRW), pada tahun 2015 sekitar 75\% peserta didik mengaku pernah melakukan tindak kekerasan di lingkungan sekolah (Ahmad, 2019). Dari data tersebut dapat di ketahui bahwa pelaksanaan pendidikan di Indonesia belum sepenuhnya memberikan perubahan positif terhadap peserta didik, maka dari itu perlu adanya peningkatan kualitas pendidikan di Indonesia.

Begitu mengkhawatirkanya keadan pendidikan saat ini dengan berbagai kasus yang menunjukkan rendahnya moral peserta didik, oleh karena itu pendidikan karakter sangat diperlukan untuk mengatasi kemerosotan moral dan karakter yang mulai ramai diperbincangkan. Pendidikan krakter seharusnya mampu disampaikan dalam setiap pelaksanaan pembelajaran yang diterapkan oleh seluruh pihak yang terlibat langsung dalam kegiatan pendidikan, khususnya sekolah, dan dalam pengajaranya haruslah dikaitkan dalam kehidupan sehri-hari, sehingga hasil dari kegiatan pembelajaran yang di dapat siswa tidak hanya dalam ranah kognitif saja tetapi mampu membuat peserta didik mengamalkanya dalam kehidupan sehari-hari sehingga hal tersebut dapat berpengaruh pada pribadi peserta didik dan dapat meningkatkan karakter peserta didik ke arah yang lebih baik.

$$
\text { Untuk membantu penguatan }
$$

pendidikan karakter tentunya diperlukan pendidik atau guru yang berkompeten. Dalam PP No. 19 Tahun 2005, Bab VI, Pasal 28 dijelaskan bahwa, ada empat kompetensi yang mesti dimiliki oleh pendidik sebagai agen pembelajaran pada pendidikan dasar, menengah maupun pendidikan anak usia dini yaitu kompetensi pedagogic, kompetensi kepribadian, kompetensi professional dan kompetensi sosial. Oleh karena itu seorang guru dituntut tidak hanya memiliki pengetahuan tentang mata pelajaran yang diajarkan nya saja tetapi guru juga harus 
mampu mengembangkan potensi peserta didik dan mampu memberi keteladanan yang dapat membangun karakter religius pada peserta didik. Keteladanan yang dimaksud tentunya keteladanan yang baik dalam membangun pribadi peserta didik, bukan sebaliknya, tetapi masih saja ada guru yang menyakiti peserta didik nya, seperti yang dilakukan oleh salah satu guru di Banten. Seorang guru Sekolah Dasar (SD) di Gunung Sari, Kabupaten Serang, Banten, berinisial A melakukan pelecehan seksual dan pencabulan terhadap 5 peserta didiknya (Yandhi Deslatama, 2020).

Seyogyanya seorang guru perlu memberikan contoh prilaku yang baik sebagai contoh keteladanan bagi peserta didik. Menurut Zakiyah dalam (Hosnan, 2016:153) menegaskan bahwa kepribadian yang dimiliki oleh seorang guru dapat menentukan apakah ia menjadi seorang guru yang dapat membina anak didiknya dengan baik, atau sebaliknya ia akan menjadi perusak bagi masa depan anak didiknya.

Lebih lanjut lagi mari kaitkan kompetensi kepribadian guru dan dampaknya terhadap pelaksanaan penguatan pendidikan karakter religius. Kompetensi kepribadian memiliki peran dan fungsi yang sangat penting dalam membentuk kepribadian anak (Hosnan, 2016:153). Dalam kehidupan sehari-hari sering kali seorang anak menirukan hal-hal yang dilakukan dan dikenakan oleh orang yang sering dia lihat dan dia temui, karena salah satu karakteristik peserta didik pada sekolah dasar adalah senang meniru. Oleh karenanya Seorang guru dengan kepribadian, tingkah laku, karakter serta akhlak yang baik dapat lebih banyak dan lebih mudah memberikan dampak positif terhadap penanaman dan penguatan karakter religius peserta didik.

Karakter religius sebagai salah satu nilai karakter yang menjadi pilar utama dalam penguatan karakter anak kearah yang lebih baik, namun karakter religius ini tidak tumbuh dengan sendirinya, melainkan perlu adanya kemauan dari diri peserta didik dan orang lain untuk menumbuhkanya. Pendidikan karakter religius pertama kali dilaksanakan di lingkungan rumah dan sekolah, dalam hal ini orang tua dan guru memiliki peran yang sangat penting dalam pembentukan karakter religius anak. Sekolah merupakan salah satu tempat yang yang mempunyai pengaruh penting dalam penguatan karakter religius anak, karena di sekolah merupakan tempat dilakukanya kegiatan pembelajaran seperti membimbing dan mengarahkan peserta didik serta tempat dilakukannya kegiatan penguatan karakter religius melalui pembiasaan-pembiasaan yang diterapkan oleh sekolah. Melalui penguatan karakter religius diharapkan peserta didik secara mandiri dapat mengalami perubahan cara berfikir, bersikap dan bertindak menjadi lebih baik. Sehingga penguatan karakter religius melalui pembiasaan yang dilakukan oleh sekolah dan guru dapat diterapkan oleh peserta didik dalam menjalankan kehidupan sehari-hari, baik dilingkungan rumah maupun sekolah.

Berdasarkan obserasi dan wawancara yang telah dilakukan peneliti, bahwa MIN 2 SERANG memiliki beberapa program dan pembiasaan-pembiasaan dalam rangka penguatan karakter religius, yaitu pembiasaan harian sebelum kegiatan pembelajaran di mulai (pembacaan asmaul husna, bacaan wudhu, bacaan solat, doa-doa harian, dan membaca surat-surat pendek dalam Al-Quran), pembiasaan mingguan (solat duha dan kuljum), pembiasaan bulanan (tahlil dan tahfiz quran).

Berdasarkan apa yang sudah dipaparkan sebelumnya maka peneliti akan menggambarkan bagaiman implementasi kompetensi kepribadian guru dalam penguatan karakter religius pada peserta didik melalui pembiasaan di kelas IV MIN 2 SERANG.

\section{KAJIAN TEORI}

\section{Kompetensi Kepribadian}

Guru merupakan teladan bagi peserta didik, apa yang dilakukan dan dikenakan guru akan diikuti dan direkam oleh peserta didik. Sesuai dengan istilah guru yaitu digugu dan 
ditiru. Oleh karena itu, guru harus memiliki kepribadian yang baik sehingga peserta didik akan mengikuti hal yang baik juga. Hal ini sejalan dengan pendapat (Hosnan, 2016: 152) yang menjelaskan bahwa kompetensi kepribadian guru yaitu kemampuan personal yang mencerminkan kepribadian yang bermental sehat dan stabil, dewasa, arif, berwibawa, kreatif, sopan santun, disiplin, jujur, rapi, serta menjadi uswatun hasanah bagi peserta didik. Kepribadian guru merupakan factor terpenting bagi keberhasilan belajar anak didik. Zakiah Drajat dalam syah yang di kutip oleh (Hosnan, 2016: 153) menegaskan bahwa kepribadian itulah yang menentukan apakah ia menjadi pendidik dan Pembina yang baik bagi anak didiknya, ataukah akan menjadi perusak atau penghancur bagi masa depan anak didiknya terutama bagi anak didik yang masih kecil (tingkat dasar) dan mereka yang sedang mengalami kegoncangan jiwa (tingkat menengah).

Begitu berperan pentingnya guru terhadap peserta didik yang memandang guru sebagai sosok yang harus ditiru, maka dari itu menjadi seorang guru harus lah memiliki kerakter yang pantas ditiru oleh peserta didik menurut syamsul yusuf dalam (Taufik, 2013) bahwa karakteristik kepribadian seorang guru adalah karakteristik pribadi yang mantap atau akhlak mulia, sebagai suri tauladan, atau figure moral bagi peserta didk. Dan Pengaplikasian kompetensi kepribadian guru dalam kegiatan pembelajaran yaitu memberikan bimbingan dan suri tauladan, secara bersama-sama mengembangkan kreativitas dan membangkitkan motif belajar serta dorongan untuk maju kepada anak didik (Hosnan, 2016: 91).

Jadi dapat disimpulkan bahwa kopetensi kepribadian seorang guru merupakan kemampuan guru dalam menampilkan diri sebagai pribadi yang baik dan teladan bagi peserta didik nya dan sebagai salah satu factor terpenting dalam mebina karakter peserta didik kea rah yang lebih baik.

\section{Pendidikan karakter}

Pendidikan karakter merupakan usaha yang dilaksanakan dan dirancang secara sistematis untuk membantu peserta didik memahami nilai-nilai prilaku manusia yang berhubungan dengan tuhan, diri sendiri, masyarakat dan lingkungan. Oleh karena itu dalam penyelenggaraanya di sekolah, pendidikan karakter harus berpijak pada nilainilai karakter dasar manusia selanjutnya dikembangkan menjadi nilai-nilai yang universal sesuai dengan kebutuhan sekolah. Menurut (Asmani, 2011: 43) bahwa pendidikan karakter bertujuan untuk meningkatkan mutu penyelenggaraan dan hasil pendidikan di sekolah, yaitu nilai-nilai yang melandasi prilaku, tradisi, kebiasaan, keseharian, dan simbol-simbol yang dipraktikan oleh semua warga sekolah dan masyarakat sekitar.

Menurut kementrian pendidikan nasional dalam (Suyadi, 2013:7) telah merumuskan 18 nilai karakter yang akan ditanamkan dalam diri peserta didik sebagai upaya membangun karakter bangsa yaitu religius, jujur, Mandiri, Kreatif, Kerja keras, Disiplin, Toleransi, Gemar membaca, Cinta damai, Komunikatif, Menghargai prestasi, Cinta tanah air, Semangat kebangsaan atau nasionalisem, Rasa ingin tahu, Demokratis, Peduli sosial, Peduli lingkungan, Bertanggung jawab. Ridwan dan Mahmud (2016: 12) meringkas atribut karakter dalam pendidikan karakter yang di aplikasikan di lingkungan sekolah dan rumah yaitu sebagai berikut:

a. Karakter utama (jujur, sabar, adil ikhlas, amanah dan menempati janji, bertangung jawab)

b. Karakter dalam berinteraksi dengan orang lain (menjaga lisan, mengendalikan diri, menjauhi perasangka dan pergunjingan, lemah lembut, berbuat baik kepada orang lain, mencintai sesame muslim, menjalin silaturahmi, malu berbuat jahat)

c. Karakter untuk sukses (hemat, hidup sederhana, bersedekah, tidak sombong, berupaya dengan sunguh-sunguh dan bersyukur). 


\section{Pembiasaan}

Pembiasaan adalah sesuatu yang sengaja dilakukan berulang kali agar sesuatu itu dapat menjadi kebiasaan, karena dalam kehidupan sehari-hari yang dibiasakan adalah sesuatu yang biasa dilakukan. Dan inti dari kebiasaan itu sendiri adalah pengulangan. Menurut (Gunawan, 2017: 93) Pembiasaan menempatkan manusia sebagai sesuatu yang istimewa yang dapat menghemat kekuatan, karena akan menjadi kebiasaan yang melekat dan spontan, agar kegiatan itu dapat dilakukan dalam setiap pekerjaan. Dan menurut para pakar dalam (Gunawan, 2017: 93) metode pembiasaa ini sangat efektif dalam rangka pembinaan karakter dan kepribadian anak.

Dalam dunia psikologi, metode pembiasaan ini dikenal dengan "operant conditioning" yang membiasakan peserta didik untuk membiasakan prilaku terpuji, disiplin dan giat belajar, bekerja keras dan ikhlas, jujur dan tanggung jawab atas segala tugas yang telah dilakukan dan metode pembiasaan ini perlu dilakukan oleh guru dalam rangka pembentukan karakter, untuk membiasakan peserta didik melakukan prilaku terpuji. Menurut (Gunawan, 2017: 95) kebiasaan yang dilakukan secara terus menerus ini yang dalam teori pendidikan akan membentuk karakter.

Berdasarkan pemaparan diatas dapat disimpulkan bahwa pembiasaan merupakan kegitan yang sengaja dilakukan berulang kali dalam rangka pembentukan karakter dan untuk membiasakan peserta didik melakukan prilaku terpuji (akhlak mulia).

\section{METODE PENELITIAN}

Penelitian ini di lakukan di sekolah MIN 2 Serang yang berlokasi di Jl. Raya Serang Pandeglang KM 13. Kampung sawah, Desa Sukamanah, Kecamatan Baros,
Kabupaten Serang, Provinsi Banten. Penelitiaan ini dilakukan secara keseluruhan, dimuali sejak peneliti mengampu mata kuliah seminar proposal pada bulan September 2020 sampai dengan bulan juni 2021.

Metode penelitian yang digunakan adalah kualitatif deskriptif yaitu penelitian dengan menggunakan keadaan secara alami dimana peneliti sebagai instrumen kunci yang bertujuan untuk menjelaskan suatu kejadian melalui wawancara, pengamatan, dan pemanfaatan dokumen Danzim dan Lincoln (1987) dalam (Moleong, 2017: 5). Kemudian yang dimaksud dengan metode deskripsi menurut sumanto (1995) dalam (Arikunto, 2011: 100) adalah metode penelitian yang memfokuskan diri pada penyelesaian masalah yang ada pada masa sekarang atau pun yang sudah terjadi. Metode ini ditujukan untuk menggambarkan fakta-fakta yang ada dan menginterpretasikannya berdasarkan hasil temuan dilapangan yang telah di dapatkan.

Teknik pengumpulan data yang digunakan adalah observasi, wawancara dan dokumentasi. Jenis Observasi yang digunakan yaitu non partisipatif hal ini dilakukan karena peneliti tidak terlibat dalam kegiatan yang terjadi di sekolah tetapi hanya sebagai pengamat, Pengamatan yang dilakukan menggunakan pengamatan berstruktur karena dalam melakukan pengamatan peneliti menggunakan pedoman observasi, jenis wawancara yang digunakan yaitu wawancara semi terstruktur jenis wawancara ini bertujuan untuk menemukan permasalahan lebih terbuka, dimana pihak yang diajak wawancara dimintai pendapat dan ide-idenya. Tabel di bawah ini akan menunjukan panduan wawancara dan observasi yang telah peneliti buat dalam melakukan kegiatan penelitian.

Tabel 1. Panduan Wawancara dan Observasi

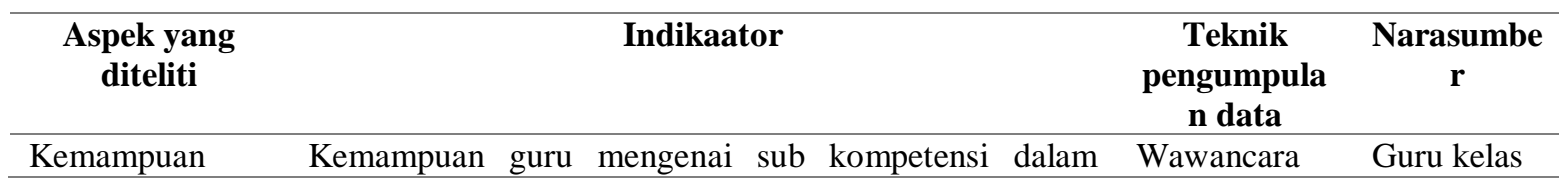


personal guru kompetensi kepribadian.

dalam Kemampuan guru dalam mengetahui penting nya fungsi

mencerminkan kepribadian bagi guru dalam memberikan keteladanan

kepribadiannya Kemampuan guru dalam mengetahui tugas dan

tanggungjawab sebagai guru.

Kemampuan guru dalam melaksanakan pendidikan

karakter.

Kemampuan guru dalam mengetahui kode etik profesi guru.

Implementasi Menampilkan diri sebagai pribadi yang jujur, tegas dan Observasi Guru kelas

kompetensi teladan bagi peserta didik dan masyarakat.

keepribadian Menerapkan kode etik profesi guru.

guru Bertanggung jawab dalam melaksanakan tugas utama

guru.

Percaya diri dalam melaksanakan tugas-tugas nya

Hasil dari Berkembangnya kemampuan peserta didik untuk Observasi peserta

implementasi menjadi manusia yang berprilaku terpuji, mandiri dan

didik

kompetensi kreatif.

kepribadian Tertanam jiwa kepemimpinan dan tanggungjawab peserta didik sebagai penerus bangsa.

Terciptanya lingkungan belajar yang aman, jujur, penuh kreativitas dan persahabatan.

Setelah didapatkanya data dari kegiatan observasi, wawancara dan dokumentasi, hal selanjutnya yang akan dilakukan oleh peneliti adalah menganalisis data. Menurut (Sugiyono, 2018: 334) menjelaskan bahwa analisis data merupakan proses mencari dan menyusun secara sistematis data yang diperoleh, dengan cara mengorganisasikan data ke dalam kategori, menjabarkan ke dalam unit-unit, melakukan sintesa, menyusun ke dalam pola, memilih mana yang penting dan mana yang akan dipelajari, dan membuat kesimpulan sehingga mudah dipahami oleh orang lain. Pada penelitian ini, peneliti akan melakukan proses analisis data kesimpulan.

Berdasarkan pendapat sugiyono dalam membuktikan keabsahan maupun validitas terhadap data penelitian yang dilakukan oleh peneliti maka peneliti menggunakan cara sebagai berikut:

1. Uji Kredibilitas

Uji kredibilitas data atau kepercayaan terhadap data hasil penelitian kualitatif dapat dilakukan dengan perpanjangan pengamatan, peningkatan ketekunan, triangulasi, analisis kasus negative, diskusi teman sejawat dan menggunakan bahan referensi (Sugiyono, 2018: 368):

a. Perpanjangan pengamatan

Dalam kegiatan perpanjangan pengamatan ini, peneliti memeriksa kembali apakah data yang didapatkan sudah benar atau tidak. Dalam hal ini peneliti peneliti kembali ke sekolah untuk melakukan wawancara dengan waka kurikulum mengenai pelaksanaan pendidikan karakter.

b. Peningkatan ketekunan

Peneliti melakukan wawancara kembali dengan lebih cermat agar data yang di peroleh dapat dipercaya.

c. Triangulasi

Triangulasi yang di lakukan oleh peneliti yaitu triangulasi sumber (sumber 1 guru kelas, sumber 2 waka kurikulum) dan triangulasi teknik (wawancara, observasi, dokumentasi).

d. Analisis Kasus Negatif

Peneliti melakukan wawancara dengan sumber yang berbeda yaitu dengan waka kurikulum untuk mencari data yang tidak sesuai, dan data yang di dapatkan dari kedua 
sumber tersebut relative sama.

e. Diskusi teman sejawat

Dalam penyusunan laporan ini peneliti melakukan diskusi dengan teman sejawat untuk meminta saran, masukan dan tanggapan terhadap penelitian yang telah dilakukan sehingga membantu peneliti dalam mengembangkan langkah selanjutnya.

f. Menggunakan Bahan Referensi

Penggunaan bahan referensi dilakukan untuk membuktikan data yang telah didapatkan oleh peneliti. Dalam laporan penelitian ini peneliti melengkapinya dengan foto-foto atau dokumen autentik sehingga menjadi lebih akurat dan dapat dipercaya.

2. Uji Transferability

Agar orang lain dapat memahami hasil penelitian ini maka peneliti membut laporan dengan penjelasan yang rinci, jelas, terstrukrtur, dan dapat dipercaya. Dengan demikian hasil penelitian ini dapat dengan mudah dipahami oleh pembaca

3. Uji dependability

Setelah melakukan penelitian dan menyusun laporan, peneliti melakukan bimbingan kembali dengan dosen pembimbing hal tersebut dilakukan agar laporan penelitian yang dibuat dapat dikatakan reliabel atau dependebel.

4. Uji confirmability

Jika hasil penelitian merupakan fungsi dari proses yang dilakukan, maka penelitian tersebut telah memenuhi standar confirmability. Maka jangan sampai proses nya tidak ada, tetapi hasilnya ada (Sugiyno, 2018: 377).

\section{HASIL DAN PEMBAHASAN}

Penelitian ini dilakukan di MIN 2 SERANG yang berlokasi di Jl. Raya Serang Pandeglang KM 13. Kampung sawah, Desa Sukamanah, Kecamatan Baros, Kabupaten Serang, Provinsi Banten. Penelitian ini dilakukan dengan tiga teknik pengumpulan data yaitu wawancara, observasi dan dokumentasi yang kemudian dianalisis dengan menggunakan model miles dan Huberman.
Dari penelitian yang telah dilakukan maka diperoleh hasil penelitian sebagai berikut:

\section{Kemampuan personal guru dalam mencerminkan kepribadianya}

Kemampuan seorang guru dapat ditunjukan dari sikap yang mengambarkan ciri khas dari dalam dirinya sendiri yang meliputi sikap, pengetahuan dan keterampilan dalam menjalankan tugas nya sebagai guru, kemampuan tersebut digunakan oleh guru untuk memberikan perubahan yang lebih baik pada peserta didik. MIN 2 Serang sebagai salah satu lembaga pendidikan formal berusaha untuk meberikan perubahan yang lebih baik pada peserta didik nya terutama pada perubahan sikap, agar terjadinya perubahan yang lebih baik pada peserta didik, MIN 2 Serang tidak hanya memberikan materi akan pengetahuan saja tetapi MIN 2 Serang juga menerapkan beberapa pembiasaan dalam rangka penguatan karakter peserta didik seperti yang sudah peneliti paparkan pada bab sebelumnya. Hal tersebut sejalan dengan UU No. 14 tahun 2005 tentang Guru dan Dosen pasal 1 bahwa seorang guru tidak hanya memiliki kemampuan akan pengetahuan saja tetapi juga harus memiliki keterampilan dan prilaku yang baik dalam menjalankan tugas nya sebagai seorang guru.

Kompetensi kepribadian guru merupakan salah satu kompetensi yang memiliki pengaruh penting dalam membina karakter anak, menurut bapak saeful selaku guru kelas di MIN 2 Serang mengatakan bahwa Kompetensi kepribadian merupakan pribadi seorang guru yang harus menunjukan kepribadian yang baik seperti cara bersikap yang baik, berbicara dengan sopan dan santun, berpakaian rapih serta memberikan contoh dan menjadi teladan yang baik bagi peserta didik, Karena segala sesuatu yang ditunjukan oleh guru akan diikuti oleh peserta didik nya, maka dari itu sebagai seorang guru haruslah menampilkan diri sebagai pribadi yang baik dan memberikan contoh yang baik bagi peserta didiknya. Oleh karena itu, karakteristik kepribadian yang harus dimiliki oleh seorang 
guru adalah pribadi yang mantap atau akhlak mulia serta sebagai suri tauladan atau figur moral bagi peserta didik syamsul yusuf dalam (Taufik, 2013).

Sebagai seorang guru haruslah memiliki pribadi yang baik agar baik jug peserta didik nya seperti yang dikatakan oleh Zakiah Drajat dalam (Hosnan, 2016: 153) yang mengatakan bahwa kepribadian itulah yang menentukan apakah ia menjadi pendidik dan Pembina yang baik bagi anak didiknya, ataukah akan menjadi perusak bagi anak didiknya. Menurut bapak saeful bahwa seorang guru dengan pribadi yang baik adalah guru yang disiplin, jujur, bijaksana, tegas, berwibawa dan dapat memberikan contoh yang baik tidak hanya bagi murid nya saja yah tetapi bagi guru-guru yang lain juga. Ciri-ciri pribadi seorang guru yang baik yang disebutkan oleh bapak seful sesuai dengan definisi kompetensi yang dijelaskan oleh (Hidayat, 2017: 13) bahwa Kompetensi kepribadian merupakan kemampuan personal yang mencerminkan kepribadian yang berwibawa, dewasa, arif, mantap dan stabil serta menjadi teladan bagi peserta didik dan berakhlak mulia.

Kemampuan personal yang dimiliki oleh seorang guru bertujuan untuk membantu memberikan perubahan sikap yang baik bagi peserta didik. Sama seperti pelaksanaan pendidikan karakter yang bentuk kegiatan nya berupa tindakan mendidik yang bertujuan untuk menyempurnakan pribadi seseorang. Pendidikan karakter mengajarkan kebiasaan cara berfikir dan berprilaku yang membantu individu untuk hidup dan bekerja sama dengan keluarga, masyarakat dan bangsa, D. Yahya Khan dalam (Asmani, 2011: 30). Oleh karena nya dalam rangka pelaksanaan pendidikan karakter, bapak saeful selaku guru kelas di MIN 2 serang menerapkan berbagai pembiasaan seperti solat duha berjamaah, tadarusan, menghafal doa-doa harian, melaksanakan piket, makan dan minum dalam keadan duduk, membuang sampah pada tempatnya dan lain sebagainya. Hal tersebut merupakan usaha yang dilakukan oleh Guru dalam membentuk watak peserta didik dengan cara memberikan keteladanan, cara berbicara atau menyampaikan materi yang baik, toleransi, dan berbagai hal yang terkait lainya (Asmani, 2011: 31).

Dari apa yang sudah peneliti paparkan di atas bahwa guru di MIN 2 Serang khusus nya guru kelas iv sudah memiliki Kemampuan personal yang seharusnya dimiliki oleh seorang guru dalam mencerminkan kepribadianya yaitu dengan menampilkan diri sebagai pribadi yang baik dan dapat menjadi teladan bagi peserta didik nya dan menjalankan tugas nya sebagai guru yang tidak hanya sekedar menyampaikan materi saja tetapi juga menerapkan berbagai pembiasaan dalam rangka pelaksanaan pendidikan karakter terutama dalam penguatan karakter religius peserta didik serta menjalankan ode etik profesi guru dengan menjadi guru yang disiplin dan taat akan peraturan yang ada

\section{Implementasi Kompetensi Yang Dilakukan Oleh Guru}

Pada masa pandemic ini Implementasi kompetensi yang dilakukan oleh guru MIN 2 Serang tidak seperti biasanya pada saat keadaan normal, terdapat beberapa peraturan dari sekolah yang mengakibatkan keterbatasan dalam melakukan berbagai pembiasaan yang biasa dilakukan. Dalam satu minggu setiap kelas di MIN 2 Serang hanya 2 kali melakukan kegiatan pembelajaran secara langsung dan sebagian besar guru di MIN 2 Serang memanfaatkan waktu tersebut untuk pengumpulan tugas dan penyampaian mater. Namun berbeda dengan bapak saeful selaku guru kelas IV MIN 2 Serang, beliau memanfaatkan waktu 2 hari tersebut tidak hanya untuk pengumpulan tugas dan penyampaian materi saja tetapi beliau juga tetap melaksanakan beberapa pembiasaan dalam rangka penguatan karakter religius.

Kegiatan pembiasaan yang dilakukan secara tidak terprogram dapat dilaksanakan dengan cara-cara seperti dibawah ini (Gunawan, 2017: 95).

a. Kegiatan rutin (pembiasaan yang 
dilakukan secara terjadwal) seperti salat duha bersama, upacara bendera, dan kegiatan yang lainya.

b. Kegiatan yang dilakukan secara spontan (kegiatan yang dilakukan secara tidak terjadwal) misalnya pembentukan prilaku seperti membuang sampah pada tempatnya, memberi salam, dan lain sebagainya.

c. Keteladanan (kegiatan dalam bentuk prilaku sehari-hari) seperti datang ke sekolah tepat waktu, berpakaian rapih, dan lain sebagainya.

Adapun pembiasaan yang dilakukan oleh bapak saeful selaku guru kelas IV MIN 2 Serang yaitu solat duha berjamaah, tadarusan, membaca asmaul husna dan menghafal doadoa harian, berdoa sebelum maupun setelah pembelajaran dan melakukan piket kelas. Karena sikap dan prilaku seorang guru sangat membekas dalam diri peserta didik sehingga ucapan, karakter, dan kepribadian guru menjadi cermin murid (Asmani, 2011: 72). Maka dari itu berkenaan dengan Implementasi kompetensi kepribadian yang dilakukan oleh guru, bapak saeful berusaha untuk menampilkn diri sebagai pribadi yang baik dengan berpakaian rapih, berbicara dengan sopan dan santun, bersikap ramah pada peserta didik, menjaga lingkungan agar terlihat bersih dan selalu mengucapkan salam ketika memasuki ruangan maupun bertemu dengan seseorang. Sehingga dapat dikatakan bahwa kepribadian yang tampilkan oleh guru dapat dijadikan panutan yang harus digugu dan ditiru sabagai menjadi contoh pula bagi kehidupan dan pribadi peserta didik (Hosnan, 2016: 91).

Selanjutnya implementasi kompetensi kepribadian guru dalam kegiatan pembelajaran yaitu memberikan bimbingan dan suri tauladan, secara bersama-sama mengembangkan kreativitas dan membangkitkan motif belajar serta dorongan untuk maju kepada anak didik (Hosnan, 2016: 91). Dan yang dilakukan oleh bapak saeful dalam kegiatan pembelajaran tidak hanya menerapkan pembiasaan yang tadi peneliti sebutkan, tetapi setelah penerapaan pembiasaan tersebut beliau tetap melalukan pengajaran dengan menyampaikan materi pelajaran, memberikan penilaian terhadap tugas yang dikerjakan oleh peserta didik, memberikan motivasi serta nasehat pada peserta didik nya. Selain itu untuk mengetahui pencapaian peserta didik yang dilakukan selama pembelajaran daring, pada saat pembelajaran ofline bapak saeful melakukan kegiatan tanyajawab mengenai materi yang diberikan pada saat daring, kegiatan tanyajawab tersebut sebagai salah satu usaha yang dilakukan bapak saeful untuk membangkitkan semangat belajar pada diri peserta didik. Dan seperti itu lah seorang guru yang harus menjadi contoh dan teladan, membangkitkan motif belajar siswa serta mendorong/memberikan motivasi dari belakang (Ki Hajar Dewantara).

Selain dari pada itu beliau juga sudah menerapkan kode etik profesi guru diantara nya yaitu membimbing peserta didik, menciptkan suasana belajar yang baik, mengembangkan mutu profesi, melaksanakan kebijakan pemerintah dan menjalin hubungan baik dengan peserta didik, orang tua peserta didik dan masyarakat sekitar (Suprapto, 2019). Selama peneliti melakukan pengamatan pak saeful selalu melaksanakan tugas nya dengan baik yaitu memberikan pengajaran, membimbing, memotivasi, memberikan contoh dan teladan yang baik bagi peserta didik tidak hanya itu beliu juga menjalin hubungan baik dengan masyarakat sekolah yaitu guru, peserta didik, serta wali murid dan melaksanakan kebijakan pemerintah untuk melaksanakan pembelajaran secara daring serta selalu mematuhi protokol kesehatan, beliau juga mengembangkan profesi nya sebagai seorang pendidik dengan mengikuti pelatihan USAID yaitu pelatihan untuk membantu meningkatkan keprofesionalisasianya sebagai seorang guru.

3. Hasil Dari Implementasi kompetensi kepribadian yang dilakukan oleh guru

Terlihat adanya perubahan pada diri peserta didik dari implementasi kompetensi 
kepribadian yang dilakukan oleh guru. Terdapat atribut karakter utama pada peserta didik (jujur, sabar, adil, ikhlas, amanah, menepati janji, bertangung jawab) Ridwan dan Mahmud (2016: 12). Peserta didik MIN 2 Serang terutama kelas IV sudah menunjukan karakter utama yang disebutkan oleh ridwan dan Mahmud yaitu mereka datang ke sekolah dengan tepat waktu sebelum dimulainya kegiatan pembelajaran, berpakaian dengan rapih, mengucapkan salam ketika memasuki ruangan maupun bertemu dengan orang lain, berbicara dengan sopan dan santun, selalu melaksanakan solat duha di pagi hari setiap hari senin, tidak pernah lupa untuk berdoa sebelum maupun setelah belajar dan sepulang sekolah mereka selalu membersihkan kelas terlebih dahulu.

Selain itu, ada juga atribut karakter lain yang dimiliki peserta didik sebagai hasil dari implementasi kompetensi kepribadian yang dilakukan oleh guru yaitu, terdapat atribut karakter dalam berinteraksi dengan orang lain pada diri peserta didik (menjaga lisan, mengendalikan diri, menjauhi pergunjingan, lemah lembut, berbuat baik, mencintai sesama, menjalin silaturahmi) Ridwan dan Mahmud (2016: 12). Yaitu peserta didik MIN 2 Serang khususnya kelas iv mereka menunjukan perubahan sikap yang baik dengan berpakaian rapih, berberbicara dengan sopan dan santun, menjalin hubungan baik dengan peserta didik lainya, tidak hanya sekedar menerima materi, arahan dan nasehat dari guru tetapi mereka juga mempraktekanya dalam kehidupan sehari-hari, mereka akan mengucapkan kata tolong jika membutuhkan bantuan dan mereka pun akan mengucapkan kata terimakasih setelah menerima bantuan dari orang lain, mereka pun menunjukan adab yang baik pada saat makan yaitu makan dan minum dalam keadaan duduk dan tidak lupa untuk membaca doa,

Pembiasaan yang diterapkan oleh bapak saeful dan kepribadian yang ditampilkanya memiliki pengaruh yang baik bagi peserta didik, peserta didik MIN 2 Serang khususnya kelas IV tidak hanya memiliki atribut karakter utama dan atribut karakter dalam berinteraksi dengan orang lain tetapi memiliki atribut karakter lain juga, yaitu atribut karakter agar peserta didik bisa sukses (hidup sederhana, bersedekah, tidak sombong, bersunguh-sungguh) Ridwan dan Mahmud (2016: 12). Atribut karakter agar bisa sukses yang ditunjukan oleh peserta didik yaitu mereka serius dan semangat dalam belajar dengan Mengerjakan tugas yang di berikan oleh guru, mendengarkan materi yang disampaikan oleh guru dan mengikuti arahan dari guru, pada saat bapak saeful bertanya kepada peserta didik secara bergantian mengenai materi pelajaran, peserta didik menjawab pertaanyaan tersebut dengan benar bahkan jika mereka lupa dengan materi nya mereka akan berusaha untuk mengingatnya agar bisa menjawab pertanyaan yang ditanyakan oleh bapak saeful dan terkadang teman nya pun membantu untuk mengingat materi tersebut bahkan membantu menjawab nya. Meskipun di sekolah tidak mengadakan kegiatan menaung mereka juga tetap melakukan kegiatan menabug di rumah secara mandiri.

\section{SIMPULAN DAN REKOMENDASI}

Berdasarkan hasil penelitian dan pengembangan yang dilakukan didapatkan kesimpulan sebagai berikut: Guru kelas IV MIN 2 Serang yaitu bapak saeful sudah memiliki kemampuan personal guru dalam mencerminkan kepribadianya dan kepribadian yang ditunjukan oleh bapak saeful sudah sesuai dengan sub kompetensi dalam kompetensi kepribadian yaitu dengan menampilkan diri sebagai pribadi yang baik dan dapat menjadi teladan bagi peserta didik nya, menjalankan tugas nya sebagai guru yang tidak hanya sekedar menyampaikan materi saja tetapi juga menerapkan berbagai pembiasaan dalam rangka pelaksanaan pendidikan karakter terutama dalam penguatan karakter religius, dan sudah menjadi guru yang sesuai dengan kode etik profesi guru yaitu dengan menjadi 
guru yang disiplin dan taat akan peraturan yang ada

Kemudian, dalam implementasi kompetensi kepribadian yang dilakukan oleh guru kelas IV MIN 2 Serang yaitu bapak saeful dapat disimpulkan bahwa bapak saeful selaku guru kelas IV MIN 2 Serang sudah mengimplementasikanya dengan menerapkan berbagai pembiasaan dalam rangka penguatan karakter religius, menampilkan diri sebagai pribadi yang baik, menjadi contoh teladan bagi peserta didik nya dan membangkitkan motif belajar siswa serta memberikan motivasi bagi peserta didik. Selanjutnya, implementasian kompetensi kepribadian guru terhadap karkter religius peserta didik memiliki hasil yang baik dan memiliki pengaruh yang baik bagi karakter religius peserta didik yaitu sudah terlihat adanya perubahan pada peserta didik dan terdapat beberapa atribut karakter pada diri peserta didik yaitu atribut karakter utama (jujur, sabar, adil, ikhlas, amanah, menepati janji, bertangung jawab), atribut karakter dalam berinteraksi dengan orang lain (menjaga lisan, mengendalikan diri, menjauhi pergunjingan, lemah lembut, berbuat baik, mencintai sesama, menjalin silaturahmi) dan atribut karakter agar peserta didik bisa sukses (menjaga lisan, mengendalikan diri, menjauhi pergunjingan, lemah lembut, berbuat baik, mencintai sesama, menjalin silaturahmi).

\section{DAFTAR PUSTAKA}

Arikunto, S. (2011). Metode Penelitian Pendidikan. Bandung: CV Pustaka Setia.

Asmani, J. M. (2011). Pendidikan Karakter di Sekolah. Jogjakarta: DIVA Press.

Gunawan, H. (2017). Pendidikan Karakter Konsep Dan Implementasi. Bandung: Alfabeta.
Hidayat, S. (2017). Pengembangan Guru Profesional. Bandung: PT Remaja Rosda Karya.

Hosnan, M. (2016). Etika Profesi Pendidik. Bogor: Ghalia Indonesia.

Hosnan, M. (2016). Psikologi Perkebangan Peserta Didik. Bogor: Ghalia Indonesia.

Suprapto, I. (2019). Upaya Mewujudkan Kode Etik Guru. tersedia pada https://disdik.purwakartakab.go.id/ diakses pada tanggal (4 juni 2021)

Kerangka acuan pendidikan karakter 2010. Tersedia pada http://www.newindonesia.org/beranda/ images/upload/dok/kurikulum/kerangk a-acuan-pendidikan-karakter-2010.pdf diakses pada tanggal (2 desember 2020).

Moleong, L. J. (2017). Metodologi Penelitian Kualitatif. Bandung: PT Remaja Rosda Karya.

Penguatan Pendidikan Karakter (PPK). Tersedia pada https://jendela.kemdikbud.go.id/v2/fok us/detail/penguatan-pendidikan-

karakter-ppk diakses pada tanggal (31 Mei 2021)

Ritongga, A. A., dan Hasanh, L. (2019). Penanaman Nilai Karakter Menurut Imam Al-Ghazali Dalam Kitab Minhajul Abidin, 8:6-7.

Sugiyono. (2018). Metode Penelitian Kuantitatif, Kualitatif dan $R \& D$. Bandung: Alfabeta.

Suyadi. (2015). Strategi Pembelajaran Pendidikan Karakter. Bandung: PT Remaja Rosda Karya.

Taufik, M. (2013). Pengantar Pendidikan. Bandung: CV. Mujahid Press. 